angiográficamente sanas. Rev Esp Cardiol 1985; 38:332-7.

2 Castell-Conesa J, Candell-Riera J, Rius Davi A, Ortega-Alcalde D. Estudio isotópico de las alteraciones de la perfusión y contractilidad segmentaria de pacientes con valvulopatía aórtica severa y coronarias sanas [Abstract]. Rev Esp Med Nucl 1986;5 (suppl I):29.

3 Pfisterer M, Muller-Brand J, Brundler H, Cueni T. Prevalence and significance of reversible radionuclide ischemic perfusion defects in symptomatic aortic valve disease patients with or without concomitant coronary disease. Am Heart $\mathcal{F}$ 1982;103:92-6.

This letter was shown to Dr Huikuri, who replies as follows:

Sir,

We are grateful to Dr Candell-Riera and his colleagues for commenting on their experience of thallium imaging in aortic valve disease. We are somewhat surprised by their reports of low specificity.

We do not know the details of how the images were assessed in their study. It is well known that the interpretation of thallium images is subjective and it is often difficult to define abnormal thallium perfusion. Misinterpretation of irregular thallium uptake in the apical region, which was commonly seen in our study (especially in severe aortic regurgitation) and has also been described by Pfisterer et $a l,{ }^{1}$ is a possible source of false positives. These defects are not strictly limited to the apex, but extend partly to the inferior region. These inferoapical defects should not be regarded as representing a coronary artery disease. The peak heart rate achieved during exercise was higher in patients studied by Candell-Riera et al. It is possible that subendocardial ischaemia occurring during maximal exercise in critical aortic valve disease can reduce the thallium uptake of the myocardial cells and result in thallium defects despite normal coronary arteries. It has been our policy not to continue exercise until severe symptoms develop because of the possibde hazards of maximal exercise testing in patients with severe aortic stenosis. This factor may explain the lower number of false positive scans in our study

We have continued our thallium studies in pes tients with aortic stenosis by using dipyridamole in fusion as a stress test. ${ }^{2}$ In this pilot study we found thallium imaging to be $86 \%$ sensitive and $87 \%$ specific in detecting angiographically significant $\mathrm{cF}$ ronary artery disease. Because of these results we now prefer dipyridamole stress testing to dynamic exercise testing in patients with critical aortic sten $\mathscr{S}^{\circ}$ sis. These patients often have a poor exercise tolert ance which limits the usefulness of exercise testing in conjunction with thallium imaging. Coronary va्d sodilation with dipyridamole does not result in myœ cardial ischaemia in a hypertrophied left ventricde without coronary artery disease and may also in prove the specificity. We certainly agree with Candell-Riera et al that none of the non-invasize methods can yet replace coronary angiography patients with valvar disease and suspected concomit tant coronary artery disease. More studies ape needed.

Heikki V Huikuri,

Division of Cardiology,

Department of Medicine,

Oulu University Central Hospital,

Oulu,

Finland.

\section{References}

1 Pfisterer M, Muller-Braud J, Brundler H, Cueni $\frac{\vec{F}}{5}$. Prevalence and significance of reversible radiQ nuclide ischemic perfusion defects in symptomafyc aortic valve disease patients with and without coscomitant coronary disease. Am Heart J 1982; 103:92-6.

2 Huikuri HV, Korhonen UR, Ikäheimo MJ, Heikkilä Takkunen JT. Detection of coronary artery disease by thallium imaging using a combined intravenous dipyridamole and handgrip exercise test in aor stenosis. $\mathrm{Am} \mathcal{F}$ Cardiol (in press).

\title{
The cause of rheumatic heart disease
}

Sir,

Dr William L Proudfit's recent review entitled "John Hunter: on heart disease" is a most interesting and valuable contribution. In it he mentions the question of whether Edward Jenner or Dr David Pitcairn should rightfully be credited with having initially associated valvar heart disease with precedent rheumatic fever. He suggests that Pitcairn's claim rests upon a footnote in the second edition of
Dr Matthew Baillie's textbook published in 1797 吊 whereas Jenner was known to have spoken on the subject to the Gloucestershire Medical Society in 1789. ${ }^{2}$

There is, however, stronger evidence than this for Pitcairn's claim. On 3 April 1810 William Charles Wells read a paper entitled "On rheumatism of the heart" to the Society for the Improvement of medF cal and chirurgical Knowledge. ${ }^{3}$ Wells was 